\title{
Comparative Research about the Contemporary Preschool Teacher Education in Germany and France
}

\author{
Lina Zhang \\ Teachers' College Shenyang University \\ Shenyang, China
}

\author{
Chunyan $\mathrm{Wu}$ \\ Saiyite Kindergarten Dadong District \\ Shenyang China
}

\begin{abstract}
By means of documentary methods, this paper compares the preschool teacher cultivation in Germany and France from the aspects of pre-service cultivation and postservice cultivation of preschool teacher education. It analyzes the differences in the performance of preschool teacher cultivation in Germany and France, and puts forward suggestions for the reform of current preschool teacher education in China: The specialization of preschool teacher education and the integration of preschool teacher education should be emphasized.
\end{abstract}

Keywords-Teacher education; Preschool education; Comparative research

\section{INTRODUCTION}

\section{A. Education for Preschool teachers}

Preschool teacher education generally refers to as teacher cultivation and training in the preschool education field, and it is a developable, continuous and integrated development process for conducting pre-service cultivation, induction training and post-service cultivation for preschool teachers as per the different periods and phases for the professional development of preschool teachers.

\section{B. Pre-service cultivation}

Pre-service cultivation refers to the study of relevant courses about the specialty learned thereby before people start to work officially, and the education objects are mainly the college students who are about to enter society. The preservice cultivation of preschool teachers refers to the process of cultivating teachers considering the basic teaching of preschool education.

\section{Post-service cultivation}

Post-service cultivation refers to the process of accepting training and education after being employed to better and more professionally get familiar with business, and it is aimed to realize the development of teacher specialization. The postservice cultivation of preschool teachers is to improve the professional quality of preschool teachers, update their professional knowledge, and reinforce the education capacity.

\section{CURRENT Status ABOUT THE EdUCATION FOR PRESCHOOL TEACHERS IN GERMANY}

\section{A. Pre-service cultivation}

After World War II, Germany started to emphasize on preschool teacher education career. Currently, the school volunteers of preschool teachers in Germany must be equipped with the graduation certificate of junior high school or the same educational level; besides, before the admission, they must receive one-year practical training at the household management department or study at household management schools for one year. Besides, preschool teachers can only get teacher qualification through passing two national examinations of the learned specialty and pedagogy. Thus, it can be seen that, Germany is extremely strict in the requirements for treating preschool education workers [1]. In course setup, it can be divided into common courses, professional courses and practical courses; common courses include sports, art education, techniques and design, music, sports, and German; Professional courses include pedagogy, psychology, sociology, social research, biological health education, correction education, children's literature and media education, laws, group management methods, theology, repentance education and ethics; Practical courses totally have 400 class hours, and occupy about $14.3 \%$ of the total class hours [2].

The preschool teacher education in Germany especially emphasizes on the combination of theory and practice in preservice cultivation, for instance, Munich Municipal Social Education Professional College recruited school volunteers for five-year cultivation, and then sends them to kindergarten or other education institutions to work. The five-year schedule is as follows: Within the first two years, it will ask students to work at kindergartens as interns, and then gain actual education experience in practice, and during the period of internship, it shall be ensured that they can monthly return to the school to receive theoretical course education for one time, discuss with teachers and solve their problems encountered during the period of internship, find and solve problems, and then after the internship is finished, they should take professional examinations. After that, in the next two years, they should go to the school to receive official professional course study, and the learning contents in these two years include two points below: Firstly, it is to conduct professional theoretical study about the education of children at the age of 
0-6; secondly, it is to conduct professional theoretical study about the education of children at the age of 6-10. However, during the period of professional study, it shall be ensured that they can weekly return to the kindergarten to participate activities for one time. In the last year, they should return to the kindergarten as interns, during which they should also return to the school to receive professional guidance every two weeks [3]. Besides, the pre-service cultivation for preschool teachers in Germany has also fully reflected the theory of emphasizing on practice and actual effect through the teaching mode. For most of the time in classrooms, they will listen to students and watch them act, and teachers are merely there to provide guidance and answer questions. All of these have improved the capacity for students to solve actual problems to some extent.

\section{B. Post-service cultivation}

Germany has a set of advanced mode -- "dual system" vocational education mode in the post-service cultivation field of preschool teachers. Dual system refers to the enterprise and the school, i.e., Enterprise and school cooperation, and the entire education training activity is organized and conducted by enterprises and vocational schools through cooperation, of which enterprises are responsible for providing places for students to practice, and vocational schools are responsible for teaching students professional knowledge and skills and it is a kind of vocational teaching mode that implements skill training for students [3]. "Dual system" attaches great importance to the combination of theory and practice, and this is quite similar to pre-service cultivation, so the preschool teachers cultivated in Germany are equipped with high quality.

Effectiveness is the most obvious characteristic of German teachers in post-service cultivation. Post-service training for preschool teachers in Germany can be divided into the training for kindergarten leader, teacher and child-care workers, offjob and on-job training, long-term training and long-term training. Most training modes of the training institution adopt menu type, and specifically, the training unit shall provide several training themes within ca certain time and then the trainer shall select the training it wants to participate as per its own demands. Most training contents are organizing experts to explain, consult and communicate with students considering the practical, and hot problems. For instance, what they should do in the face of infants' safety threats? As a country of immigrants, how to educate infants under the background of diversified culture, and how to validly communicate and jointly educate with parents.

\section{CURRENT StATUS ABOUT THE EDUCATION FOR PRESCHOOL TEACHERS IN FRANCE}

\section{A. Pre-service cultivation}

France is one of the countries where preschool education was firstly developed worldwide. In France, school volunteers should study at normal colleges after graduating senior high school and passing the examination, and they should firstly accept 3-year college-level basic education and then add twoyear teacher specialized cultivation. The former three years of higher education have laid a good foundation for the comprehensive quality of students, and the latter two years of teacher specialized education will be mainly emphasized on the knowledge and skills requested for preschool education work. Professional cultivation includes the contents of four aspects: Basic cultural education, discipline education, internship and individualized cultivation. With respect to course setup, normal courses include French, mathematics, science and technology, geography, sports, drawing and music; Professional courses include pedagogy, the history of education, psychology, sociology, preschool pedagogy, learning theory, training of immigrant children, infant school activity requirements, philosophy and research methods; In the first year of the practical courses, use 6 weeks to work at kindergartens as interns, and then in the second year, use 12 weeks to work at kindergartens as interns [4].

Except for learning the theoretical courses about the basic education, students majoring in preschool education in France should also participate in practical education activities under the guidance of teachers, for instance, working at kindergartens as interns for a short term, and applying the professional theoretical knowledge learned in classrooms in the practice of kindergartens. When learning at school, students can enjoy paid welfare and teacher treatment, and in case of being engaged in preschool education after graduation, they must teach for 10 years. Besides, French kindergarten teachers are quite demanding in employment, and the kindergarten teacher qualification can only be obtained after accepting four-year and above higher education, obtaining academic and master degree, participating and passing the national employment and recruitment examination; once being employed, they cannot work immediately, instead, they should accept two-year training at college teacher education colleges, and then work as interns at kindergartens for one year, and then become the official kindergarten teacher after passing the examination.

\section{B. Post-service cultivation}

France attaches great importance to the post-service cultivation of kindergarten teachers. French Ministry of Education has clearly stipulated that it implements the unique system with the pre-service cultivation and post-service cultivation being mutually supplemented: From the fifth teaching year to five years before the retirement, each kindergarten teacher can enjoy the right to receive continuous education, and the accumulative time for continuous education is one academic year; Each kindergarten teacher who has worked for above 5 years can enjoy 36-week in-service education in the follow-up teaching career, and should participate in 1 training every 5 years; each teacher should annually complete no less than $18 \mathrm{~h}$ continuous education training, and then constantly enrich and update knowledge, improve the education and teaching capacity, teachers' quality and management capacity, and understand various theories, and concept development status about education, etc.[5].

Along with the arrival of the information era, French government has formulated "emergency plan" for France to enter the information society; the government has input huge funds in the training of kindergarten teachers, promoted information and communication technology in preschool 
education, make all kindergarten teachers realize the importance of computer and use information technologies to realize modernized education. In France, there are many training approaches, kindergarten teachers can select independently as per their own demands, and all the training expenses incurred thereby shall be paid by the school.

\section{SUGGESTIONS FOR OUR COUNTRY BASED ON THE SYSTEM OF THE EDUCATION FOR PRESCHOOL TEACHERS IN GERMANY AND FRANCE}

The preschool teacher education system in Germany and France are extremely sound, and we can use such experience as references.

\section{A. Integration of education for preschool teachers}

The preschool teacher education has realized integration in Germany and France, i.e., pre-service education and postservice education can be mutually complemented. However, we fail to solve the integration of teacher education very well, and fail to realize the mutual compensation of pre-service education and post-service education, so we should conduct the reform of preschool teacher education system focus on the pre-service education, without neglecting the importance of post-service cultivation; we must change the pre-service education contents and the mode of post-service training, ensure that during the time of post-service cultivation, offset the weakness of pre-service education through post-service cultivation, so that we can improve the quality of our kindergarten teacher team, realize pre-service and post-service integration and the preschool teacher education integration.

Besides, the training expenses incurred in the post-service cultivation of kindergarten teachers should also be borne by the kindergarten in whole or in part, and the kindergarten teachers shall also personally select the training theme. The most important thing is that, we must change our training mode, and the so-called expert lecture and visiting training have a small influence on improving teachers' quality. We should also combine enterprises and schools, of which enterprises can provide sites, and schools can provide training, to truly realize the integration of preschool teacher education.

\section{B. Professionalization of education for preschool teachers}

The preschool teacher education has realized professionalization in Germany and France, i.e., there are professional institutions implementing professional educational cultivation, and educational training for both preservice education and post-service education; besides, there are also professional institutions implementing strict authentication for the infant teacher qualification.

Currently, the pre-service cultivation of kindergarten teachers has become the multi-channel, multi-layer, multispecification and multi-mode infant teacher education system that regards normal colleges as the subject, with the participation of other education institutions [6]. However, since our country lacks in the professional recognition institutions of infant teacher education, lots of teachers have become kindergarten teachers, without professional preservice cultivation; meanwhile, they don't have any opportunities to accept professional post-service training during their in-service period.

Meanwhile, many students cultivated by vocational technical colleges and majoring in preschool education have become the main teacher source for kindergartens of our country. However, the pre-service cultivation implemented by vocational technologies emphasizes more on the development of professional skills, such as the piano, drawing, singing, and dancing, which have seriously neglected the study of preschool education theories. However, the pre-service training implemented in normal colleges emphasizes more on the study of professional theories and the total proportion of professional courses and general courses can reach to $2: 1$, and the proportion of education practice is extremely small, and the added practical courses are merely implemented perfunctorily, for it is merely visiting certain kindergarten[7]. Thus, the students cultivated through normal colleges and vocational technical colleges and other institutions are not competent for the education and teaching work at kindergartens.

To sum up, in order to improve the pre-service and postservice professional level for preschool teacher education in our country, it is requested to reflect the professionalization in course setup, and the combination of theories and practice is the only valid approach to verify the truth, and also the correct choice for the professionalization of preschool teacher education.

\section{CONCLUSIONS}

Through the comparative research about the preschool teacher education in Germany and France, we have obtained the following education experience that will contribute to the development of preschool teacher education in our country: It is requested to emphasize on the combination of effectiveness, theories and practice, the integration of pre-service and postservice education, and realize professional course setup and professional teacher qualification recognition. It is expected that, on the basis of doing research, we can further reform and perfect the cultivation mode of preschool teacher education in our country and promote the preschool education to develop better.

\section{REFERENCES}

[1] Lijun QIN Research about the Teacher Education in Germany [C]. 2014

[2] Xinghua WANG. Current Status and Future Trend about the Preschool Education in Germany [D] Comparative Education Research 2015

[3] Lei ZHANG, Ximei HAN. Enlightment of German "Dual System" Vocational Education Mode for the Continuous Education of Infant Teacher in Our Country [N]. Journal of Beijing Xuanwu Hongqi Sparetime University 2014:86

[4] Changjie DENG and Xingchun XU. Historical Characteristic about the Social Identity Evolution of Infant Teacher in France [J] 2015

[5] Mingli FAN. Teacher Quality Assurance Mechanism in French Kindergartens and the Enlighten [J] 2013 Infant Education (Education Science)

[6] Yan HUANG Research about the Modern Chinese Preschool Education Teacher Cultivation and Management [D] 2013 Southwest University

[7] Yanqing YANG. Investigation and Reflections on the Current Status about the Setup of Professional Courses for Preschool Education [D] 2013. 